\title{
Efficiency Assessment of Jazan Port Based on Data Envelopment Analysis
}

\section{Dr. Hanaa Abdelaty Hasan Esmail}

\author{
College of Business Administration, Jazan University, KSA, Theba Acadamy- Egypt
}

Email: hanaa_abdelaty001@yahoo.com

Doi:10.5901/mjss.2016.v7n3s1p320

\section{Abstract}

Transport sector has an important role in all economic countries, especially marine ports that represent the backbone of any country and it has lot of beneficial effect on development process. The economic impact of port sector is usually measured by lot of indicators for example value addition and employment. But in this paper, I argue for increased attention by maritime economists to review, analyze, and summarized port efficiency by using DEAP(Data Envelopment Analysis Programs). This analysis is made by compiling input \& output table collected from statistical report. The author has used DEA program to measure ports efficiency by suggesting some constraints on inputs and outputs. The efficiency is determined through division of weights of sum of outputs to the sum of inputs, where we assume the weights of inputs and outputs are greater than zero. In the case of the Saudi Arabian ports and their efficiency, the results show that Jazan port is considered inefficient plus most of the ports are also inefficient. The study tries to suggest some benefits provided the government is interested to develop and apply them.

Keywords: Ports, DEA, Input-Output, Maritime , JEC, Solver

\section{Introduction}

Ports in Saudi Arabia are considered to be contributing effectively to the development of the national economy and connection between countries. Ports also identify trade between worlds.

Ports developed due to the ancient Egyptians who are the first people to have used the seas and oceans. Then came the Phoenicians, The Greeks and The Romans.

Ports have crucial role in increasing trade relationship between the countries and also have direct effects on stability of local markets and have an impact on all development plans that are put by the government of the countries in the world.

Saudi Arabia owns a network and transport links, it has a network of roads with a total length of $67.893 \mathrm{KM}$ (including 4.479 KM) of high ways and double roads. Additionally about $91.107 \mathrm{KM}$ of agricultural roads.(1)

Saudi Arabia owns near of 23 multi functional ports (trade - industrial - oil shipping and fishing) including the ports of Jeddah and Jazan on the red sea coast , Dammam and Jubail on the Arabian gulf coast .

Jazan region has gained economical importance in Saudi Arabia. The reason being the closeness of Bab- Al Mandab which connects countries from the African and Asian continents and due to its own lot of economic resources, investments, agriculture and also resources in tourism.

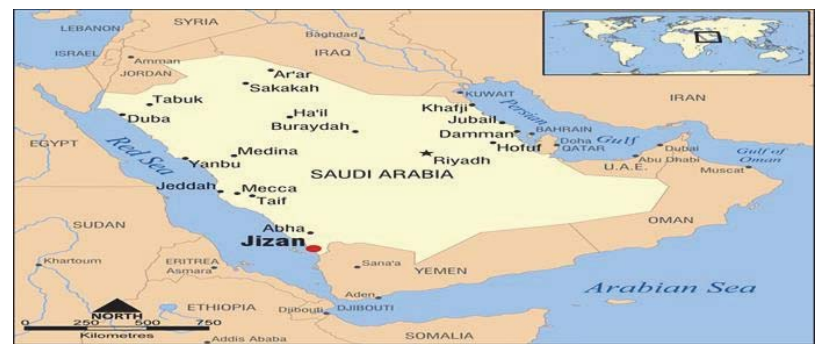

Jazan port is considered as one of the main ports that links Asia ,Europe and Africa. which will contribute to the

1 - http://www.ports.gov.sa 
provision of materials, products and goods for people particularly in southern areas and generally in all Saudi Arabia . Among the factors that increased the importance of the port's existence were lot of changes in region have been established such economics cities to meet needs of these projects from raw materials that contribute to the implementation.

There are countries that benefit greatly from the marine coasts where there are huge commercial fleets roaming around the world, east and west such as Greece, and Japan.

While others are still in the process of attempts such as the Arab countries particularly some of the gulf countries as kingdom of Saudi Arabia. There are also countries that still rely on foreign fleets.

There is no doubt that the ports offer investment opportunities in the field of international trade particular in the area of shipping and freight as well as marine services which call for identifcitation of the ports and its inclusion of assets owned wholly or leased, which in turn may contribute to alleviate unemployment which will be witnessed by KSA.

\section{Ports}

Shipping is a global economy which accounts for $90 \%$ of total volume of world trade. Shipping has a big role in the completion of business transactions between the different continents of the world whether related to primary materials or food or manufactured products.

Shipping is one of the cheapest transport all types both in terms of material costs or capabilities. It has lot of features with no need for continuous changes, except at the beginning and the end for the roads and port's platforms.

Because of the importance of shipping and its added advantages it is considered as the backbone of the national economy and the basis of sustainable development. So without the means of different transport there will be adversely affected investment opportunities and business conditions among some other countries. This study has so many objectives such as determination of the benefits, problems of ports, how ports facilitate foreign trade volume, and try to assess all maritime ports in Saudi Arabia plus adding policies and future plans that have a role in economic development.

\section{Literature Study}

\subsection{Ports development}

Nowadays Ports are not only hubs of transport and exchange cargo but also help economic development of their country where is contribute to the transfer of $75 \%$ of world trade addition it's contribute to improving the balance of payments of those countries and to provide employment opportunities for national labor, building and flourishing cities that are located on the sea Rickard Bergqvist (2013).. Also It is an important to achieve a better development in all ports activities E.Paipai (1999), investigate the impacts from port development activities have similar time scale as the development itself, expect changes on environmental resources are permanent (eg, land reclamation changing flow pattern and sediment transport).other impacts from port is represent of port operation will be the same as long as the operation do.

According to (Chin -Shan lu ; Marcus Tukan 2012), their studies observed many ports that investing billions of dollars in ports infrastructure to improve their existing facility to able to accommodate increases in shipping trade volume which followed by increases size of vessel, cargo and services requirements. It also mentions that many ports require to expand their ports to meet business demand and finding it challenging to develop with economic environmental and social issues balance to grow sustainably. The essence of developing large ports are considered the main objective to all countries to provide with lot of benefits based on (Asta et al 2011).

AS we know Ports has been playing main role economically through its imports' and exports' processes to any country especially heavy goods. Thus all countries give importance to sea ports, because it is the main gateway to obtain income.

Generally in the present paper I try to give attention to Saudi Arabia Ports instead of Adoption of its economy on oil industry especially after fall in oil prices by more than half. Also transportation sector especially sea ports can attract many investors to create opportunities of job, addition to increase productivity.

There is no doubt that improvement seaports that will influence the economy in the short term by creating more jobs and will shift economic growth in long run by achieving efficiency.

According to Araujo( 2010), most Brazilian ports has a high cargo handling cost by world standards. Several authors have drawn attention to the challenges in port infrastructure that compromise the system's efficiency and raise concerns the possibilities of operating depletion because of lack of investment (Marchetti et al ). 


\subsection{Efficiency of DEA}

There are several studies that informed to use DEA models to assess sectors performance and its efficiency. Where finding (Charnes et al 1978), is analyzed one unit at any time. It is considered that a unit is operating in order to determine the weights of their inputs and outputs. The same should be done for all other units, determining the weights according to the particular optical each one. Then if the unit is efficient, will get the maximum rate in the evaluation of several other units. some units can only be judged efficient through their own criteria; other, or even having the freedom to choose any weights for their inputs and outputs, can be show efficient .

Regarding productivity (Sami Ben, Goaied 2015), study the importance of operational efficiency on hotel profitability that is considered a major target for investors, by using Data Envelopment Analysis (DEA) and the Return On Assets and its result is that the best average for efficiency and for ROA is found in large hotels. Hotels with high indebtedness show an average of high efficiency but lower profitability than less indebted hotels. Also Some studies have shown that (DEA) model can be used in evaluating service sector of public and private hospitals by (Yaghoub et al.2012).

In the current study focused light on the possibility of using DEA model through an assessment of the ports of Saudi Arabia then give a clear vision of the importance of developing inefficient ports while George Kobina (2015), used DEA models to measure The efficiency of African ports. As well as Nobrega (2005), Fialho, (2006) evaluate ports by checking whether they are meeting the demands or not .Thus, Informed some port features and products handled in ports of Brazil, is intended to set a score to identify those that are more efficient in the operation of its services. While (Anguibi, 2015, A. A. Noora1 et al ,2013) has different definitions and measurement of DEA .

Stand out numerous studies on port efficiency as Bichou (2009), Referring to (Haibo Wang et al, 2015) The development of port not only the basic factor to improve efficiency but also must emphasis on importance of energy that make ports better. Regarding to (Luiz et al 2012), not only used DEA to identify the DMUs in different productions scales, but also to evaluate the behavior of the port authorities.

According to use DEA to analyze efficiency or inefficiency we find tha Fadzlan Sufian (2007), examine the impacts of risk factor on Islamic bank efficiency, then he reach to foreign banks have exhibited higher technical efficiency compared with others by depending on spearman correlation.

\subsection{Methodology}

This study is based on using data envelopment analysis (DEA) to evaluate and classify development possibilities of Marine Ports in KSA especially Jazan port. The information was collected from ports authority depending on statistics through the year 2014.

Generally Technical efficiency of a production unit is measured by comparing the observed values and the great values of their products (outputs) and / or (inputs). It's comparison can be made by the ratio between the observed output and the maximum production data available resources, or the ratio between the minimum amount of resources and the quantity effectively used, given the amount of generated products (2). Whatever the approach, the technical efficiency is always greater than or equal 1 . A measure of efficiency of 1 means that the unit is technically efficient.

\subsection{Data envelopment analysis}

The data envelopment is a program in which we can build a model by using solver through Excel program to determine the efficiency of ports in KSA. DEA analyzes each Decision Making Unit (DMU) separately, measuring the efficiency of their practices for the whole set of DMUs participants sample across the distance between the border and that particular observation. Thus, this technique provides a performance assessment relating to all units of the assembly.

\subsection{Model}

DEA models One measure of efficiency can be described as:

Productivity efficiency = product(output) (s) / input (s) (1) weighted sum of inputs /weighted sum of products Efficiency .

According Charnes et al. (1978), this technique lets you work with models with fixed product and variable product

${ }^{2}$-M.J.Farrell, Measurement of Productive efficiency (1957), Journal of Royal Statistical Society, Vol.120, No3.PP253-290. 
to scale. Furthermore, these models can type additives (reduction ingredient (s) and increased product (s), multiplicative, input-oriented or oriented product.

Sample selection for efficiency analysis included all KSA ports which provided information on their number of inputs and outputs from the following sources: "Yearbook Statistical Port 2004 : 2014

The oriented models aim to increase the amount of products while maintaining product available resources. The increase products can be specified as follows:

$\mathrm{s}^{\prime}=\varphi \mathrm{Y}_{\mathrm{t}}+\delta \mathrm{s}^{\mathrm{l}}$

where $\mathrm{s}^{\prime}:$ is the slack in products

$\varphi \quad$ : is the proportional increase of products

$Y \quad$ : is vector products and observed

$\delta s^{\prime} \quad$ :It is the individual additional increase of the residual products.

DEA is nonparametric and also comparative approach for identifying efficiency, it compares each port for example (DMU) to determine best port among KSA ports .

We can use this approach to estimate ports efficiency scores. It is a convenient benchmarking tool to evaluate operational practices of ports. This approach supposes outputs and inputs, and we can assume that transformation of inputs on outputs is made with the same technology by depending on Micro soft Excel (solver) The model-oriented product with variable returns to scale used in this study was:

Minimize Inputs is representing $\sum_{i}\left(w_{i} x_{i \leq x_{0}}\right) . E$

Or Maximize Outputs is representing $\sum_{i}\left(w_{i} y_{i \leq y_{0}}\right)$

Where weight $\sum_{i}\left(w_{i}=1\right)$

$\mathrm{E}, w_{i}>=\varphi$ where $\mathrm{E}$ : efficiency score, $w_{i}$ : are weighs for ports

$x_{i}:$ Inputs for ports

$x_{0}$ :are inefficient inputs

$y_{i}:$ output for ports

$y_{0}$ : inefficient output

According to the different studies using the Data Envelopment Analysis (DEA) we can depend on output and inputs are argued by the data availability. So this paper uses two output and three inputs to measure of port performance for the year 2014 where :-

Output

Y1: is representing Ports Exports

Y2: is representing Number of Loaded Vessels

Inputs

$\mathrm{X} 1$ : Ports Imports

$\mathrm{X} 2$ : Number of Discharged Vessels

$\mathrm{X} 3$ : Number of Berth

Table (1). Port Data of Saudi Arabian ports

\begin{tabular}{|c|l|c|c|c|c|c|}
\hline DMU No & Port & $Y_{1}$ & $Y 2$ & $X 1$ & $X 2$ & $X 3$ \\
\hline 1 & Jeddah & 20546532 & 166 & 42176850 & 4627 & 58 \\
\hline 2 & Jazan & 26412 & 8 & 1530359 & 82 & 12 \\
\hline 3 & Damam & 5875240 & 147 & 21472973 & 1734 & 22 \\
\hline 4 & Yanbo commercial & 50324 & 14 & 2441604 & 185 & 9 \\
\hline 5 & Yanbo Industrial & 31056836 & 993 & 6435388 & 287 & 0 \\
\hline 6 & Diba & 264623 & 0 & 878666 & 679 & 8 \\
\hline 7 & Jubal commercial & 3588232 & 85 & 3198364 & 455 & 16 \\
\hline 8 & Jubal Industrial & 37242573 & 1419 & 8629585 & 187 & 27 \\
\hline 9 & Ras Elkhair & 2172658 & 86 & 118407 & 87 & 7 \\
\hline
\end{tabular}

Source: www.ports.gov.sa . statistical information (2000-2014) 


\subsection{Result by DEA Model:}

Each DMU in previous table was calculated by the DEA method, the results that we obtain from Excel (solver Model) were represented in the following table.

Table (2). The Efficiency Score of ports \& Ranking

\begin{tabular}{|c|l|c|c|}
\hline DMU No & Port & Efficiency Score & Ranking \\
\hline 1 & Jeddah & 1.4 & 2 \\
\hline 2 & Jazan & 0.9 & 4.5 \\
\hline 3 & Damam & 0.9 & 4.5 \\
\hline 4 & Yanbo commercial & 0 & 8.5 \\
\hline 5 & Yanbo Industrial & 0.03 & 7 \\
\hline 6 & Diba & 0 & 8.5 \\
\hline 7 & Jubal commercial & 1.04 & 3 \\
\hline 8 & Jubal Industrial & 0.5 & 6 \\
\hline 9 & Ras Elkhair & 1.6 & 1 \\
\hline
\end{tabular}

Also we can determine efficient port and inefficient ports, if the score after using DEA(solver) equals one or greater it means efficient port, if it's less than one it will be an inefficient port in table (3).

Table (3). Classifying KSA Ports

\begin{tabular}{|c|l|c|c|}
\hline DMU No & Port & Efficiency Score & Ranking \\
\hline 2 & Jeddah & 1.4 & Efficiency \\
\hline 4.5 & Jazan & 0.9 & Inefficiency \\
\hline 4.5 & Damam & 0.9 & Inefficiency \\
\hline 8.5 & Yanbo commercial & 0 & Inefficiency \\
\hline 7 & Yanbo Industrial & 0.03 & Inefficiency \\
\hline 8.5 & Diba & 0 & Inefficiency \\
\hline 3 & Jubal commercial & 1.04 & Efficiency \\
\hline 6 & Jubal Industrial & 0.5 & Inefficiency \\
\hline 1 & Ras Elkhair & 1.6 & Efficiency \\
\hline
\end{tabular}

Source: Calculated by using solver

Jazan port is an important hub despite the small size of the port compared to other ports, but it is responsible for receiving some important commodities such as cattle and barley, which are distributed throughout the Kingdom. Jazan City Development recently gave Jazan port an economic value able because of the establishment of the JEC, which depending on many of the construction materials such as cement, iron and these materials move through Gizan port maritime .

\section{Managerial Implications}

Sample size of nine main ports in Kingdom of Saudi Arabia: This study has some constraints that must be considered when we use (DEA) these constraints based on two output and three inputs' ports that collected from annual statistical of Saudi Arabia -Ports Authorties2012.

The research empirically states that Saudi Arabian ports are most important sources of income, like the rest of the States but recently there are some events that could affect their economies, particularly their dependence on oil only as the sole source of income, so necessary to assess the ports of Saudi Arabia Especially Jazan Port. Then authors used the best approach Data Envelopment analysis (DEA) to evaluate Jazan port and classify them on the basis of their efficiency. 


\section{Conclusion}

Maritime sector is very important economic lifeline. It also is considered a window of supporting trade for some industries and attract many investments. As we conclude, we understand from this study that there is a need for promotion and development of maritime ports to reflect the positive effects represented in the increased income and increasing employment. Therefore the Kingdom of Saudi Arabia must establish a joint-stock company whose main task will be the development and operation of all Saudi ports and the centrality of all ports by increasing the number of platforms.

Saudi Arabia is one of the biggest oil producers globally but also is the largest consumer. It is recently suffering from a structural imbalance as a result of its dependence on this as the sole source of income. As oil is a non-renewable source and with the many challenges currently facing the country like increase of population and scarcity of water, health and education and some of the political crisis it is therefore necessary to extend the attention to seaports and place them in the planning by the government in the near future.

\section{Recommendation}

1. Achievement of sustainable development in the maritime transport sector through the expansion of freight (lot of food, as well as manufacturing materials to and from different countries.

2. Raise the competitiveness between different ports.

3. Try to use mainly maritime transport to travel between governorates of the Kingdom of Saudi Arabia , and also provide special terms for the transfer of pilgrims especially regions' pilgrims and neighboring area isn't as it is in the case of shipping of citizens from Jazan to Farsan Island.

4. Government should put strategic plan to Saudi Arabia Maritime by developing this sector.

5. Review all laws and rules related to Saudi Arabian ports.

6. Encourage competition in all Maritime activities and preventing any monopoly policy.

7. Development policies should be improved to strategically plan which help in the reduction of road accidents Especially in the cities that are away from religious sites.

8. Expand the ports to state-of- the- art of technology.

9. Government sectors should be interested in infrastructure by:

a) Continuous development of ports and make all platforms deep .

b) Prepare big network between ports and industrial regions .

c) Use modern equipment that will increase cargo ratio and also raise profitability levels of companies.

10. Related to improvement in shipping sector service we can repost these :-

a) Reduce all tax and services wages to be able to compete with all neighboring ports.

b) Renewing all data and Saudi Arabian instructions compatible with all development in ports .

c) Reduce land rent in ports and encourage private sector to increase private sectors to increase investment. This will reflect positively on imports and exports rules and maximization of benefits of Saudi Arabia ports .

d) Increase restrictions on perishable goods that can be spoilt to avoid any loss during transfer goods .

e) Make lot of facilities to check all free containers and don't consider it as imports goods .

f) The port timings can be extended beyond the present working hour.

g) The ports can be kept open during vacation and holidays to avoid trouble due to storage of goods .

h) Increase the available facilities for transit goods .

11. Saudi Arabia Government should renew transport sectors especially maritime ports . that will help increasing of economic growth by depending on main advantages of each port, and also will achieve lot of economic , social and environment benefits such as :-

- Investment and Productivity Benefit

- Employment

- Tourism

- Safety and security by reducing road accidents

- Keeping air, water quality and change climate

a. Investment and Productivity Benefit: Port development may be reduced according to overall transport cost and improving reliability while it is confirmed that supply side improve significantly. Port development is expected to provide benefits for port itself and consumers.

b. Employment: Port improvement can create jobs and will contribute to local community growth 
through employment or community development. Ports can contribute to support government that keep unemployment at a low level.

c. Tourism: Port development can improve tourism sector for example the development of the maritime sector may motivate local tourism(such as pilgrim movement from his region to any region near of Mecca ) also may increase activity in ports and economy opportunity for tourism in local and national.

\section{References}

A. A. Noora1 , E. Sarfi1 , E. Noroozi (2013) , Influence of deleting some of the inputs and outputs on efficiency status of units in DEA, Journal of Data Envelopment Analysis and Decision Science Volume: 2013, P 1-10. www.ispacs.com/dea

Almotairi , B., Flodén, J., Stefansson, G., Woxenius, J., (2011), Information flows supporting hinterland transportation by rail: Applications in Sweden, Research in Transportation Economics 33(1),15-24

Andersen, A.; Petersen, C. N. 1993. A Procedure for Ranking Efficient Units in DEA, Management Science 39(10): 1261-1264.

Angubi China Flora Carine (2015), " Analyzing the Operational Efficiency of container Ports in Sub-Saharan Africa ", Open Journal of Social Sciences ,3,10-17. http://www.scirp.org/journal/jss

Asta Maryte , Marius and Goda (2011)Possibilities of Sustainable Development of Small Recreational Ports , Environmental Research, Engineering and Management, No. 4(58), P. 48-58

Araujo, C. (2010), The port infrastructure consuming competitive advantage. http://www.comexblog.com.br/logistical

B.A Blonigen and W.W.Wilson, (2006)" New measures of ports efficiency using International Trade Data "NBER Working Paper No.12052.

Bichou , K (2009) port Operations, Planning and logistics, lioyd's practical shipping Guides, Informalaw. London . Uk.pp364

Charnes, A., Cooper, W.W and Rhodes, E. (1978) Measuring the efficiency of DMUs, European Journal of Operational Research, 2, p. 429-444

Chin-Shan Lu, Kuo-Chung San, Chi-Chang Lin (2012). Identifying crusial sustainability assessment criteria for international ports.

Cristina Acosta, Ana Silva and Milton Lima (2011), data envelopment analysis application (DEA) to measure efficiency in Brazilian ports , Journal of Transport Literature Vol. 5, n. 4, pp. 88-102.

Doyle, J. R.; Green, R. 1994. Efficiency and Cross- Efficiency in Data Envelopment Analysis: Derivatives ,Meanings and Uses, Journal of the Operational Research Society 45(5): 567-578.

FARREL, M. J. (1957) The measurement of productive efficiency. Journal of the Royal Statistic Society, London, v. 120, n. 3, p.253-290.

George Kobina ,(2015), Assessment of Port Efficiency in West Africa Using Data Envelopment Analysis, American Journal of Industrial and Business Management, http://www.scirp.org/journal/ajibm

Haibo Wang, Dahuo, Jaime Ortiz, (2015), Assessing Energy Efficiency of port Operations in China - A Case Study on Sustainable Development of Green Ports, Open Journal of Social Sciences

J.Tongzon, (2001), efficiency Measurement of selected Australian and other International ports using Data Envelopment Analysis "Transportation port A:policy and Practice, Vol.35, No2, PP113-128.http://www.scirp.org/journal/jss

Marchetti, D. S. and Pastori, A. (2006) Investment Potential Dimensioning for the Port Sector. BNDES Sector, no. 24, p. 3-34

Marcus Tukan , Tri Achmadi , Sjarief Wijaja (2012) , Selection of Pilot Ports and Effect of long Dock Investment to economic growth with an Island , Social Sciences and Humanities journal, ISSN-L: 2223-9553, ISSN: 2223-9944 Vol. 3, No. 3

M .J. Farrell, (1957) Measurement of Productive efficiency, Journal of Royal Statistical Society, Vol.120, No3.PP253-290.

Otieno Robert Kennedy, Banomyong Ruth (2011) , Sea-Port Operational Efficiency: An Evaluation of Five Asian Ports Using Stochastic Frontier Production Function Model , Journal of Service Science and Management, 4, $391-399$ (http://www.Scirp.org/journal/jssm)

Nobrega, Carlos (2005) Estatistico Yearbook (2004). Director-General of ANTAQ in 2004, Brasilia, December 2005.

Paipai, E. (1999). Guidelines for Port Environmental Management.

Porcelli, F. (2009) Measurement of Technical Efficiency. A Brief Survey on Parametric and Non-Parametric Techniques.

Raballand, G., Refas, S., Beuran, M. and Isik, G. (2012) Why Does Cargo Spend Weeks in Sub-Saharan African Ports?: Lessons from Six Countries. World Bank Publications, Washington DC. http://dx.doi.org/10.1596/978-0-8213-9499-1

Rickard Bergqvist(2013), Developing Large-Scale Dry Ports - The Case of Arriyadh ,Open Journal of Transportation Technologies. (http://www.scirp.org/journal/jtts)

Sami Ben Aissa, Mohamed Goaied (2015) , Determinants of tourism hotel profitability in Tunisia, The Role of managerial efficiency , Tourism Management Journal 52 (2016) 478-487 www.elsevier.com

Stahlbock, R. and Voss, S. (2008) Operations research at container terminals: a literature update, OR Spectrum, 30(1), pp. 1-52.

T. J. Coelli, "Estimators and Hypothesis Tests for a Stochastic Frontier Function: A Monte Carlo Analysis," Journal of Productivity Analysis, Vol. 6, No. 3, 1995, pp. 247-268. doi:10.1007/BF01076978

T. J. Coelli, D. S. P. Rao, C. J. O'Donnell and G. Battese, "An Introduction to Efficiency and Productivity Analysis," 2nd Edition, Springer, Berlin, 2005.

United States International Trade Commission (2009) Sub-Saharan Africa: Effects of Infrastructure Conditions on Export Competitiveness, Third Annual Report. US International Trade Commission, Washington DC.

WANG, S. (2013). Essential Elements in Tactical Planning Models for Container Liner shipping. Maritime Policy Management, 54 (2), pp. 84-99. 
Wang, T.F., Song, D.W. and Cullinane, K. (2002) The Applicability of DEA to Efficiency Measurement of Container Ports. Proceedings of the International Association of Maritime Economists Conference, Panama, 13-15 November 2002, 13-15.

Yaghoub Sheikh, Abdul V , Reza Vahid, Ali E , Saeed D(2012), Public and Private Hospital Services Reform Using Data Envelopment Analysis to Measure Technical, Scale, Allocative, and Cost Efficiencies, Health Promotion Perspectives, Vol. 2, No. 1, P: 28-41 